\title{
The Changes of Natural Microflora in Liver Sausage with Kimchi Powder during Storages
}

\author{
Hyoun Wook Kim, ${ }^{1,2}$ Na-Kyoung Lee ${ }^{1}$, Mi-Hwa Oh², Cheon-Jei Kim¹, and Hyun-Dong Paik ${ }^{1 *}$ \\ ${ }^{1}$ Division of Animal Life Science and Bio/Molecular Informatics Center, Konkuk University, Seoul 143-701, Korea \\ ${ }^{2}$ National Institute of Animal Science, Rural development Administration, Suwon 441-706, Korea
}

\begin{abstract}
The objectives of this study were to apply the Baranyi model to predict the growth of natural microflora in liver sausage with added kimchi powder. Kimchi powder was added to the meat products at $0,1,2$, and $3 \%$ levels. To determine and quantify the natural microflora in the meat products, total plate counts and counts of anaerobic bacteria and lactic acid bacteria were examined throughout the $28 \mathrm{~d}$ of storage. The obtained data were applied to the Baranyi growth model. The indices used for comparing predicted and observed data were $B_{f} A_{f}$, root mean square error (RMSE), and $R^{2}$. Twelve predictive models were characterized by a high $R^{2}$ and small RMSE. The Baranyi model was useful in predicting natural microflora levels in these meat products with added kimchi powder during storage.
\end{abstract}

Key words: liver sausage, kimchi powder, Baranyi model, microflora

\section{Introduction}

With the recent growth of the Korean agro-food industry, Korean consumers have shown increasing concerns over agro-food safety and have put more emphasis on the diversity, quality, and health effects of agro-food. The increase in the volume of international agro-food trade complicates agro-food safety issues. A recent survey demonstrated that Korean consumers tend to choose safer agro-foods over cheaper ones, indicating that they are particularly concerned about agro-food safety (Choi and Kim, 2006).

Recently, health-conscious consumers have been demanding functional and healthy meat products. Functional meat and meat products are produced by feeding functional material to livestock or by adding functional materials to meat products, respectively (Jimenez Colmenero, 2000; Kim et al., 2011, Yang et al., 2002; Youssef and Barbut, 2011). Available functional meat products are diverse and include products such as jerky, sausage, liver sausage, etc., due to the different sources (various types of meat and poultry; organ meats, including liver; and

\footnotetext{
*Corresponding author: Hyun-Dong Paik, Division of Animal Life Science and Bio/Molecular Informatics Center, Konkuk University, Seoul 143-701, Korea. Tel: 82-2-2049-6011, Fax: 82-2-455-1044, E-mail: hdpaik@konkuk.ac.kr
}

other sources, such as back fat; etc.), spices and other functional additives, processing procedures (comminution, curing, smoking, drying, and packaging), and processing equipment used in their production (Cheo, 2009). The large diversity in processing parameters can cause variations in the effectiveness of the processing procedures used to inactivate bacterial populations that may be present in the raw materials. Moreover, adding functional additives such as kimchi powder to meat products may influence the microbial populations present in the product, and thus, the microbial safety of meat products should be evaluated. However, lactic acid bacteria (LAB) are known to be major lactic acid producers in food products and have been characterized as the main spoiling flora of many cooked meat products (Borch et al., 1996; Samelis et al., 2000a; Vasilopoulos et al., 2007; Matamoros et al., 2010). When stored anaerobically and under refrigeration, e.g. through vacuum packaging or modified atmosphere packaging, LAB will dominate the spoilage process (Vermeiren et al., 2004). The metabolic activity of LAB results in spoilage appearing as sour, off-flavors, off-odors, milky exudates, slime production, swelling of the package through gas production and discoloration such as greening (Samelis et al., 2000b).

Traditionally, the microbiological safety of foods has been established via challenge tests. These tests simulate the effect of environmental conditions on food, in terms 
of growth and proliferation of spoilage and pathogenic microorganisms (Roberts, 1995). Challenge tests can provide data useful in determining the safety and shelf-life of food under set conditions. However, challenge tests have been criticized as an expensive, labor intensive, time-consuming, and non-cumulative research tool (McDonald and Sun, 1999). More recently, challenge tests have been considered as only giving modest assurance of product safety in the food chain (Notermans and Veld, 1994; Baranyi and Roberts, 1995; Roberts, 1997). The inadequacy of challenge tests and the desire for a safe and wholesome food supply has led to the development of a relatively new discipline called predictive microbiology (McMeekin et al., 1993).

In this context, the objectives of this study were to predict the growth of natural microflora in liver sausage to which kimchi powder had been added at $0,1,2$, and $3 \%$. The obtained data were applied to the Baranyi model for bacterial growth, and predicted and observed data were compared for the $B_{f}, A_{f}$, root mean square error (RMSE), and $R^{2}$.

\section{Materials and Methods}

\section{Preparation of kimchi powder}

Commercially produced kimchi was purchased from a local market and fermented at $4^{\circ} \mathrm{C}$ for $30 \mathrm{~d}$. Fermented kimchi was minced with a cutter (Cutter C4 VV, Sirman, Italy) and vacuum-packaged in polyethylene bags. The vacuum-packaged kimchi was immediately frozen at -20 $\pm 1^{\circ} \mathrm{C}$ until used. In order to prepare kimchi in powder form, it was heat-treated with a hot air dryer (Enex-Co600 , Enex, Korea) at $60 \pm 1^{\circ} \mathrm{C}$. Samples were dehydrated until a constant weight was reached $(<15 \%$ final moisture) and were then ground to $<0.5 \mathrm{~mm}$ ( $35 \mathrm{mesh}$ ) in size. The powder was stored in a deep freezer $\left(-70^{\circ} \mathrm{C}\right)$ until further use.

\section{Preparation of liver sausage}

Fresh pork meats were purchased from a pilot plant at Konkuk University and pork back fat, pork liver, and pork skin were also collected from a slaughter house, in Seoul, Korea. The manufacturing process was divided into 2 steps, involving production of cured and emulsified portions of pork meats including fresh pork meat, pork fat, pork skin and pork liver. The cured portion, emulsified portion, and pork liver were then mixed and chopped using a $3 \mathrm{~mm}$-plate. Two percent isolated soy protein, $0.44 \%$ nitrite pickle salt (NPS), and kimchi powder were added to this mixture, which was then blended for $15 \mathrm{~min}$ before being stuffed into fibrous casings (approximate diameter of $72 \mathrm{~mm}$ ), using a motorized sausage stuffer (IS-8, Sirman, Italy). The kimchi powder was added at levels of $0,1,2$, and $3 \%$, based on the control formula weight. After stuffing, the liver sausages were dried in a smoker (ES-1, ETL Testing Laboratories Inc., USA) at $55^{\circ} \mathrm{C}$ for $30 \mathrm{~min}$, smoked at $65^{\circ} \mathrm{C}$ for $60 \mathrm{~min}$, and cooked at $75^{\circ} \mathrm{C}$ for $2 \mathrm{~h}$. The cooked liver sausages were then cooled in cold water for $3 \mathrm{~min}$ and stored at $4^{\circ} \mathrm{C}$ until testing.

\section{Microbial analysis}

To quantify the natural microflora in a meat product, the total plate counts (TPC), anaerobic bacteria, and LAB were enumerated throughout the storage $(28 \mathrm{~d})$ at $5^{\circ} \mathrm{C}$. Preparation and microbial analyses were based on standard methods described in the FDA Bacteriological Analytical Manual (BAM; FDA, 2010). For each sampling, $10 \mathrm{~g}$ of meat product was aseptically transferred into a sterile stomacher bag, and $90 \mathrm{~mL}$ of sterile $0.1 \%$ peptone water was added. The sample was then homogenized in a stomacher (Masticator-Paddle-Blender, IUL Instruments, Spain) for $2 \mathrm{~min}$ at normal speed and aliquots were plated out directly or as 10 -fold dilutions in $0.1 \%$ peptone water. After serially diluting each sample in sterile peptone water, $0.1 \mathrm{~mL}$ aliquots of each sample were separately plated onto each of 2 duplicate agar plates. Total plate count (TPC) for aerobic bacteria was evaluated by incubating inoculated Plate Count Agar (PCA; Difco, USA) at $35 \pm 2^{\circ} \mathrm{C}$ for $24 \pm 2 \mathrm{~h}$, and anaerobic bacteria were determined by spread-plating on PCA using a BBL anaerobic jar (Difco) at $35 \pm 2^{\circ} \mathrm{C}$ for $24 \pm 2 \mathrm{~h}$. LAB counts were determined using lactobacilli MRS agar (Difco) at $35 \pm 2^{\circ} \mathrm{C}$ for $24 \pm 2 \mathrm{~h}$. After incubation, plates with 30-300 colonies were chosen for counting. All analyses were performed 3 times, with 2 samples for each replication, and counts were expressed as colony-forming units per gram (CFU/ g).

\section{Application of Baranyi model in liver sausage}

The growth data were analyzed using Baranyi and Roberts's equation (Baranyi and Roberts, 1994). The growth model was expressed mathematically in the following equations (1) and (2). The logarithm of the cell numbers, $\log N$, is given as follows:

$$
y(t)=y_{\max }+\mu_{\max } A(t)-\frac{1}{m} \ln \left(1+\frac{e^{m \mu_{\max } a(t)}-1}{e^{m\left(y_{\max }-y_{0}\right)}}\right)
$$


Where, $A$ is defined as

$$
A(t)=t+\frac{1}{v} \ln \left(\frac{e^{-v t}+q_{0}}{1+q_{0}}\right)
$$

Where $q_{0}$ is the normalized concentration of an unknown substance critically needed for cell growth and represents the initial physiological state of the cell population, $\mu_{\max }$ is the maximum specific growth rate (log $\mathrm{CFU} / \mathrm{g} / \mathrm{d}), y$ is the bacterial count in $\log (\mathrm{CFU} / \mathrm{g})$ units at time $t$, and $y_{0}$ is the initial bacteria count in $\log (\mathrm{CFU} / \mathrm{g})$ units at time $0, y_{\max }$ is the maximum cell density in $\log$ $(\mathrm{CFU} / \mathrm{g})$ units. The parameter $q_{0}$ is related to lag time $\left(t_{\text {lag }}\right)$, which is calculated from the value of $q_{0}$ and $\mu_{\text {max }}$ as in equation (3). For convenience, if the environment is constant, a lag parameter can also be derived in the Baranyi model. Consider the formula (2) given for $A(t) . A(t)$ approximates the function $t-\lambda$ more and more as $t$ increases, where

$$
\lambda=\frac{\ln \left(1+\frac{1}{q_{0}}\right)}{v}
$$

$\lambda$ is gradual delay in time. Baranyi et al. (1993) proved mathematically that if the asymptote of $A(\mathrm{t})$ is a function of the form $t-t_{0}$, where $t_{0}$ is a constant, then the classical definition of the lag time (Pirt, 1975) is very close to $t_{0}$. Therefore, it is reasonable to define $t_{\text {lag }}$ by the equation (3).

The average parameters of $y_{0}, \mu_{\max }, y_{\max }$, and lag time $\left(t_{\text {lag }}\right)$ in this study were determined using the MicroFit ${ }^{\circledR}$ version 1.0 (Institute of Food Research, UK), which fitted the integrated form (Baranyi and Roberts, 1994, 1995) to the data set of average plate counts during storage.

To assess the liver sausage microflora, the significant difference of the averages of the obtained parameters, was statistically examined by least squares analysis using PROC GLM of SAS version 9.1.

\section{Evaluation of experimental data}

The variability of the data was evaluated, with means and standard deviations calculated with Microsoft Excel and the MicroFit ${ }^{\circledR}$ program, under given conditions and at given storage times in accordance with the Baranyi and Roberts (Baranyi and Roberts, 1994, 1995). The indices used for comparisons of predicted and observed data were the determination coefficient $\left(R^{2}\right), \mathrm{RMSE}$, and the modified bias factors and accuracy factors $\left(B_{f}, A_{f}\right.$, respectively); see equation (4) and (5) (Skandamis and Nychas, 2000).

$$
\begin{aligned}
& B_{f}=\exp \left[\frac{\sum\left(\ln y_{\text {predicted }}-\ln y_{\text {observed }}\right)^{2}}{n}\right] \\
& A_{f}=\exp \left\{\sqrt{\left.\left[\frac{\sum\left(\ln y_{\text {predicted }}-\ln y_{\text {observed }}\right)^{2}}{n}\right]\right\}}\right.
\end{aligned}
$$

where $y$ is the response variable and $n$ is the number of observations. Perfect agreement between predictions and observations leads to bias and accuracy equal to 1.0. An $A_{f}$ value higher than 1 indicates that predicted values are larger than observed values (Yoon et al., 2006).

The RMSE is the average difference between the model and the data points. It provides a more intuitive measure of how well the model fits the data. It has the same units as the data (typically log CFU/g) (equation (6)).

$$
R M S E=\frac{R S S}{d f} \sqrt{\frac{\sum\left(\mu_{\text {observed }}-y_{\text {predicted }}\right)^{2}}{d f}}
$$

Where RSS is the residual sum of squares and $d f$ is the degree of freedom. $F$-values were also calculated and compared with $F$-table values.

\section{Results and Discussion}

\section{Analysis of parameters on the Baranyi model}

To determine the number of the natural microflora in the liver sausage, the TPC, and the counts of anaerobic bacteria, and LAB in the sausage, to which different amounts of kimchi powder $(0,1,2$, and $3 \%)$ had been added, were enumerated during the $28 \mathrm{~d}$ in which the sausage was stored at $5^{\circ} \mathrm{C}$. On the basis of the observed data, microbial growth models of TPC, anaerobic bacteria, and LAB were estimated by the function of Baranyi and Roberts.

Table 1 shows the estimated parameters, viz. the mean \pm SD of $y_{0}, y_{\max }, \mu_{\max }$, and $t_{\text {lag }}$, obtained from predictive models, at different kimchi powder levels. Because the kimchi powder could contribute to the initial bacterial load, the initial bacterial counts $\left(y_{0}\right)$ for the TPC, anaerobic bacteria, and LAB differed after drying (day 0), depending on the level of kimchi powder.

Based on all 4 statistics, we can conclude that the Baranyi model can predict microbial growth very well and is reliable for predicting the effects of adding kimchi powder to liver sausage on TPC, and anaerobic bacteria and LAB counts. The number of natural bacteria (TPC, anaerobic bacteria, and LAB) in the control sausage gradually increased during $28 \mathrm{~d}$ of storage, and the LAB of the control sausage exceeded $6.0 \log (\mathrm{CFU} / \mathrm{g})$. All the kimchi 
Table 1. Parameters (mean \pm SD) of growth of the total plate counts, anaerobic, lactic acid bacterial counts estimated on the basis of the Baranyi model in liver sausage

\begin{tabular}{|c|c|c|c|c|c|}
\hline \multirow{3}{*}{$\begin{array}{c}\text { Bacterial } \\
\text { type }\end{array}$} & \multirow{3}{*}{$\begin{array}{l}\text { Treat- } \\
\text { ments }\end{array}$} & \multicolumn{4}{|c|}{ Parameters } \\
\hline & & $y_{0}$ & $y_{\max }$ & $\mu_{\max }$ & $t_{\text {lag }}$ \\
\hline & & \multicolumn{2}{|c|}{ Log CFU/g } & $\begin{array}{c}\log \\
\mathrm{CFU} / \mathrm{g} / \text { day }\end{array}$ & $\mathrm{D}$ \\
\hline \multirow{4}{*}{$\begin{array}{c}\text { Total plate } \\
\text { counts }\end{array}$} & $\mathrm{C}$ & $2.23 \pm 0.05^{\mathrm{d}}$ & $4.62 \pm 0.03^{\mathrm{d}}$ & $0.65 \pm 0.03^{b}$ & 13.7 \\
\hline & $\mathrm{T} 1$ & $2.41 \pm 0.05^{\mathrm{b}}$ & $4.89 \pm 0.03^{\mathrm{c}}$ & $0.53 \pm 0.03^{\mathrm{c}}$ & 13.14 \\
\hline & $\mathrm{T} 2$ & $2.34 \pm 0.05^{\mathrm{c}}$ & $14.8 \pm 0.03^{\mathrm{a}}$ & $0.34 \pm 0.03^{\mathrm{d}}$ & $10.22 \pm 0.39$ \\
\hline & $\mathrm{T} 3$ & $2.63 \pm 0.05^{\mathrm{a}}$ & $5.08 \pm 0.03^{\mathrm{b}}$ & $0.70 \pm 0.03^{\mathrm{a}}$ & $13.39 \pm 0.39^{b}$ \\
\hline \multirow{4}{*}{$\begin{array}{c}\text { Anaerobic } \\
\text { bacterial } \\
\text { counts }\end{array}$} & $\mathrm{C}$ & $1.97 \pm 0.05^{\mathrm{d}}$ & $3.37 \pm 0.03^{\mathrm{d}}$ & $0.39 \pm 0.03^{\mathrm{d}}$ & 10.99 \\
\hline & $\mathrm{T} 1$ & $2.26 \pm 0.05^{b}$ & $5.25 \pm 0.03^{\mathrm{a}}$ & $0.84 \pm 0.03^{\mathrm{c}}$ & 12.16 \\
\hline & $\mathrm{T} 2$ & $2.26 \pm 0.05^{\mathrm{b}}$ & $4.42 \pm 0.03^{b}$ & $1.06 \pm 0.03^{\mathrm{b}}$ & $13.01 \pm 0.39^{b}$ \\
\hline & $\mathrm{T} 3$ & $2.52 \pm 0.05^{\mathrm{a}}$ & $4.30 \pm 0.03^{\mathrm{c}}$ & $2.60 \pm 0.03^{\mathrm{a}}$ & $13.75 \pm 0.39^{\mathrm{a}}$ \\
\hline \multirow{4}{*}{$\begin{array}{c}\text { Lactic acid } \\
\text { bacterial } \\
\text { counts }\end{array}$} & $\mathrm{C}$ & $2.01 \pm 0.05^{\mathrm{d}}$ & $5.39 \pm 0.03^{\mathrm{c}}$ & $1.57 \pm 0.03^{b}$ & $12.62 \pm 0.39^{\mathrm{c}}$ \\
\hline & $\mathrm{T} 1$ & $2.28 \pm 0.05^{\mathrm{c}}$ & $6.58 \pm 0.03^{\mathrm{a}}$ & $1.26 \pm 0.03^{\mathrm{d}}$ & $12.04 \pm 0.39^{\mathrm{d}}$ \\
\hline & $\mathrm{T} 2$ & $2.50 \pm 0.05^{\mathrm{b}}$ & $6.57 \pm 0.03^{b}$ & $2.05 \pm 0.03^{\mathrm{a}}$ & $13.21 \pm 0.39^{b}$ \\
\hline & $\mathrm{T} 3$ & $2.52 \pm 0.05^{\mathrm{a}}$ & $5.12 \pm 0.03^{\mathrm{d}}$ & $1.48 \pm 0.03^{\mathrm{c}}$ & $13.49 \pm 0.39^{\mathrm{a}}$ \\
\hline
\end{tabular}

All data is given as mean \pm SD.

${ }^{1}$ Treatments comprised dried kimchi powder. Control, meat batter without kimchi powder; T1, meat batter with $1 \%$ kimchi powder; $\mathrm{T} 2$, meat batter with $2 \%$ kimchi powder; T3, meat batter with $3 \%$ kimchi powder.

${ }^{\mathrm{a}-\mathrm{d}}$ Means within a column with unlike superscript letters are significantly different $(p<0.05)$. treated sausages (T1, T2, and $\mathrm{T} 3$ ) showed similar tendencies to the control (C) in terms of TPC, anaerobic bacteria, and $\mathrm{LAB}$. In the range of 1,2 , and $3 \%$ kimchi powder, treatments did not show any particularly hazardous results, when these $y_{\max }, \mu_{\max }, t_{\mathrm{lag}}$ were compared to the control values.

\section{Application of Baranyi model}

The predictive models for aerobic bacteria in liver sausage are shown in Fig. 1. The TPC of control and all treated sausages increased between day 0 and $28 \mathrm{~d}$ of storage, reaching a maximal population $\left(y_{\max }\right)$ between 4.62 and $14.8 \log$ CFU/g (Table 1). Adding kimchi powder to $1 \%$ (T1) and $2 \%$ (T2) resulted in lower $\mu_{\max }$ values than in the control (Table 1), and T2 showed the slowest bacterial growth rate at $0.34 \log \mathrm{CFU} / \mathrm{g} / \mathrm{d}$. However, $3 \%$ kimchi powder (T3), at $0.70 \log \mathrm{CFU} / \mathrm{g} / \mathrm{d}$, showed a faster bacterial growth rate than did the control. Control samples showed the longest $t_{\text {lag }}, 13.79 \pm 0.39 \mathrm{~d}$, while all treated samples showed shorter $t_{\text {lag }}$ than control (Table 1).

Fig. 2 shows predictive models for anaerobic bacteria in liver sausage during the $28 \mathrm{~d}$ of storage. The parameters for anaerobic bacteria showed similar tendencies to the aerobic bacteria for initial $\left(y_{0}\right)$ and maximal bacterial
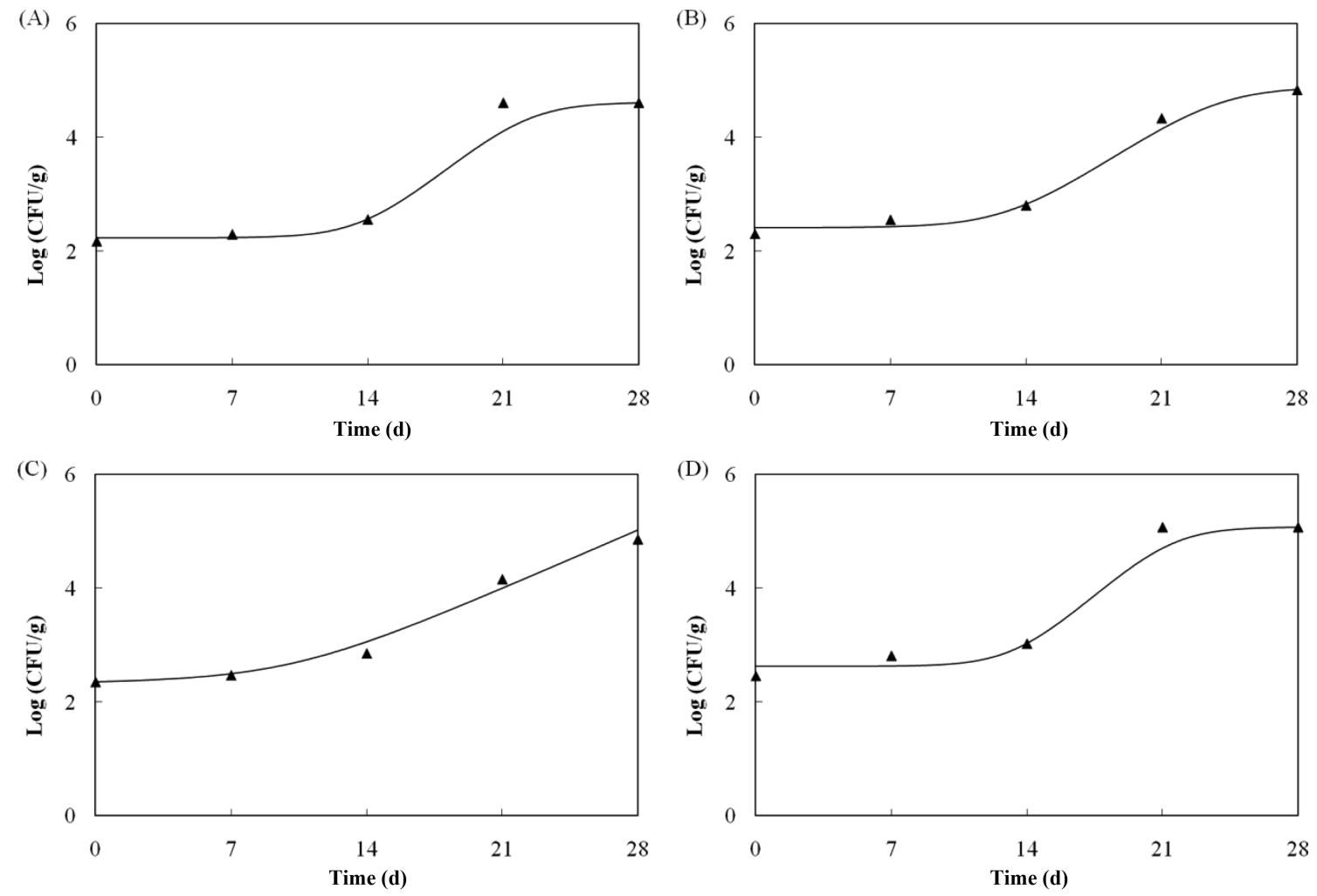

Fig. 1. Changes of aerobic bacteria in liver sausage containing kimchi powder [(A) Control, (B) T1, (C) T2, and (D) T3], estimated on the basis of the Baranyi model ( - , predicted data; $\Delta$, experimented data). 
counts $\left(y_{\max }\right)$ (Table 1). All parameters in the $\mu_{\max }$ value were significantly different between the 4 groups in the anaerobic bacteria model $(p<0.05)$. The $t_{\text {lag }}$ of T3 was the highest at $13.75 \mathrm{~d}$ (Table 1).

The predictive models for LAB in liver sausage are shown in Fig. 3. LAB growth curves showed that control, $\mathrm{T} 1, \mathrm{~T} 2$, and $\mathrm{T} 3$ have tendencies similar to each other, independent of the level of kimchi powder, and distinct from the curves for TPC and anaerobic bacteria (Fig. 3). There was little difference in the initial counts $\left(y_{0}\right)$ and the maximal counts $\left(y_{\max }\right)$ between control and all kimchi-treated sausages. T2 showed the highest growth rate (2.05 Log $\mathrm{CFU} / \mathrm{g} / \mathrm{d})$, and $\mathrm{T} 1$ showed the longest $t_{\text {lag }}$ (13.49 d).

The Baranyi model assumed that during lag phase, the specific growth rate depended on the need of each cell to synthesize intracellular substances, for instance, RNA or other cytoplasmic components such as ribosomes (Baranyi and Roberts, 1994). Under constant environmental growth conditions, the Baranyi model considers that the lag time, $t_{\text {lag }}$, is inversely proportional to the maximum specific growth rate, $\mu_{\max }$. In models of TPC and anaerobic bacteria, for control and treated sausages, the $t_{\text {lag }}$ value was inversely proportional to the $\mu_{\max }$ value (Table
1). Difficulties in estimating the length of the lag phase were not caused by the lack of proper models but by lack of detailed knowledge of the physiological phase of bacterial growth. A population may include cells at the stages of active growth or lag phase, or they may be damaged, busy repairing damage, or at a stage of dying from severe damage (McMeekin and Ross, 2002).

\section{Evaluation of experimented data}

To evaluate the models, the $B_{f}, A_{f}$, RMSE, and $R^{2}$ indices were used for comparisons of predicted and observed data (Table 2). The predictive parameters of TPC, anaerobic bacteria, and LAB were characterized by a high determination coefficient $R^{2}$; high $R^{2}$ values result from a small number of degree of freedom.

The $R^{2}$ values for the model of TCP in liver sausage were 1.007 (control), 0.988 (T1), 0.908 (T2), and 0.978 (T3) (Table 1). The higher the $R^{2}$ values $\left(0<R^{2}<1\right)$, the better the prediction by the model (Duffy et al., 1994; Ross 1999). The bias factor $\left(B_{f}\right)$ and accuracy factor $\left(A_{f}\right)$ values in the control deviated slightly from 1.0, which would have indicated perfect agreement (Table 1). The $B_{f}$ of 0.999 in the control sausage indicated that the predictive total plate counts exceeded the observed counts by
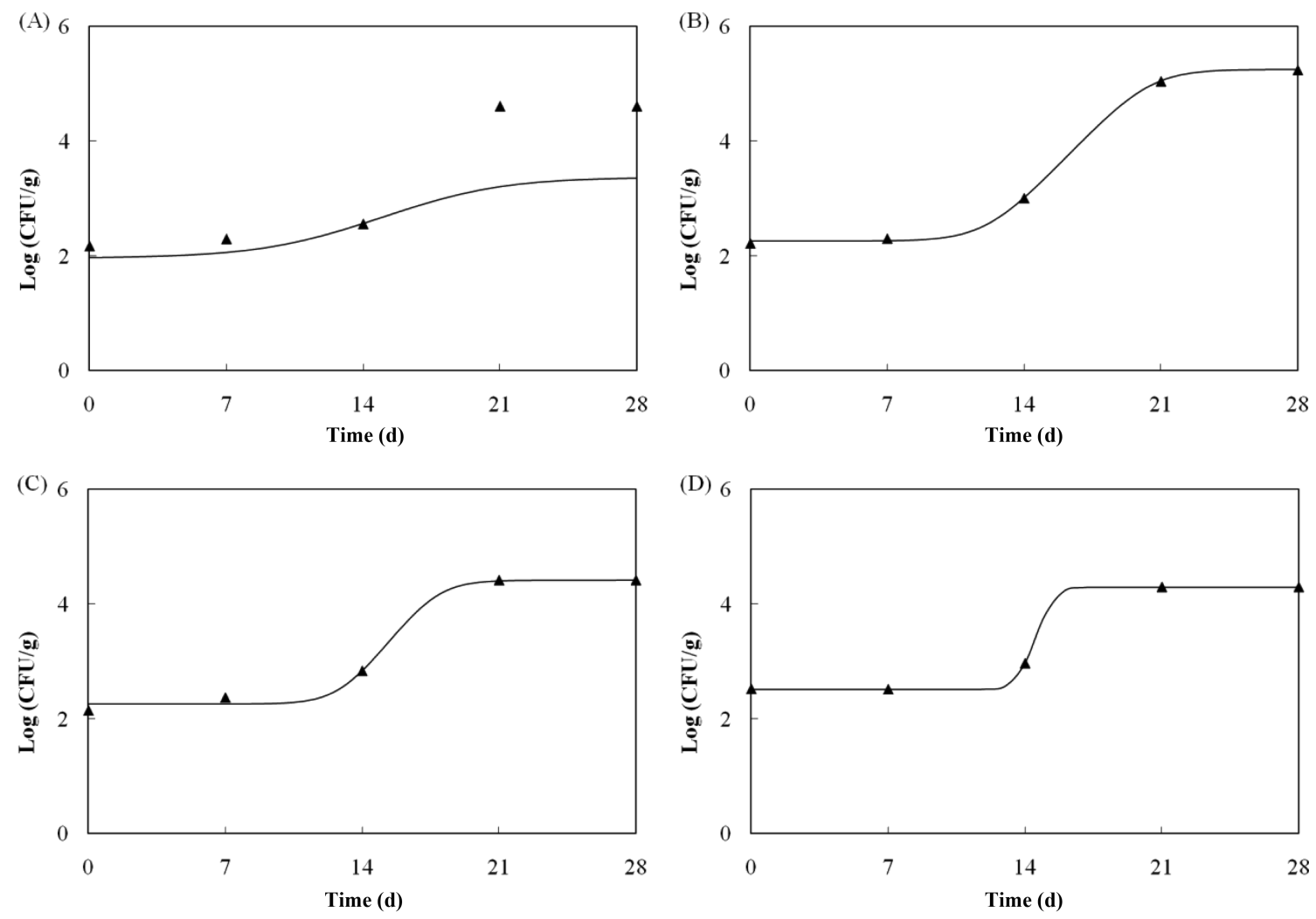

Fig. 2. Changes of anaerobic bacteria in liver sausage containing kimchi powder [(A) Control, (B) T1, (C) T2, and (D) T3], estimated on the basis of the Baranyi model ( - , predicted data; $\Delta$, experimented data). 

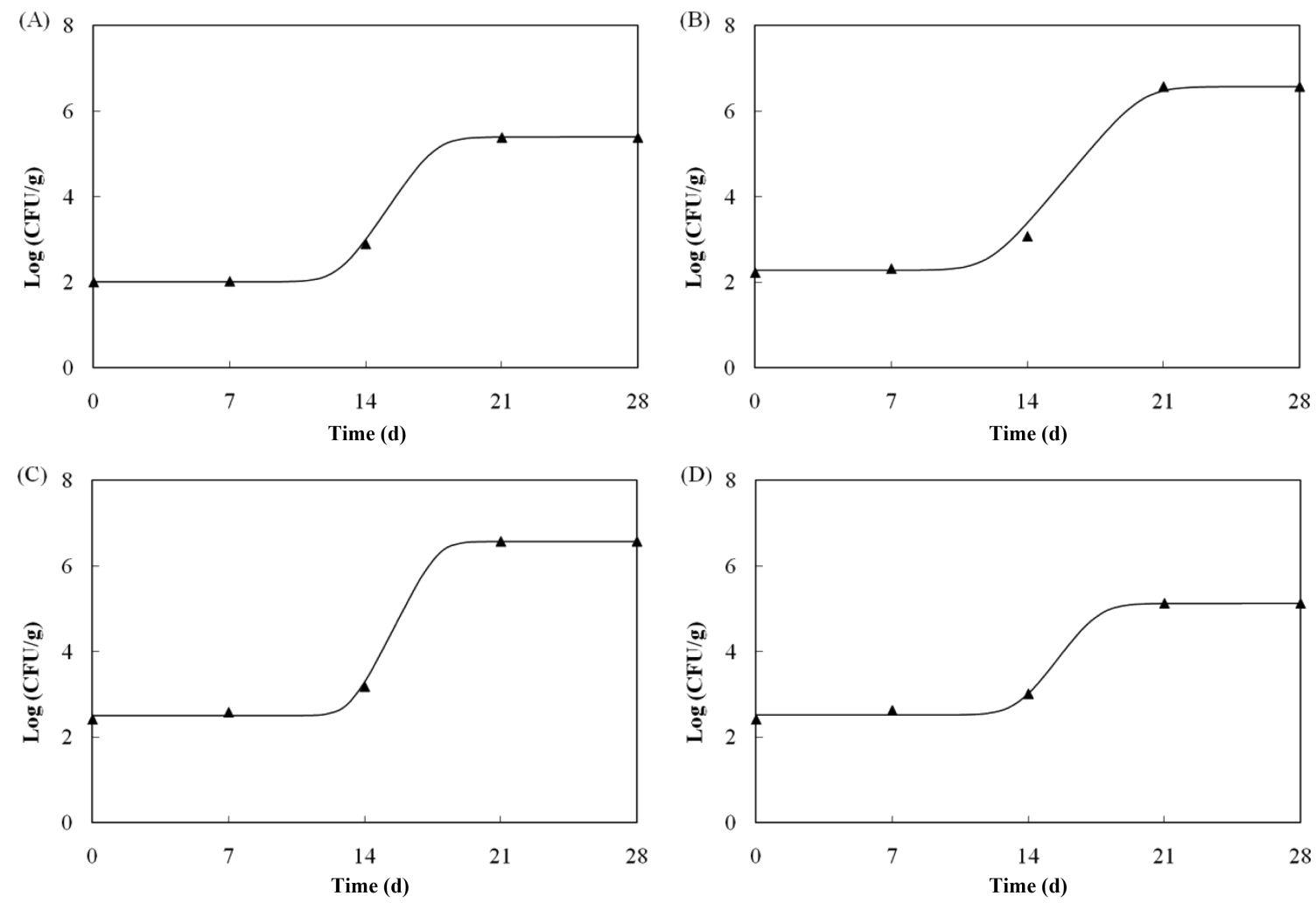

Fig. 3. Changes of LAB in liver sausage containing kimchi powder [(A) Control, (B) T1, (C) T2, and (D) T3], estimated on the basis of the Baranyi model ( - , predicted data; $\Delta$, experimented data).

Table 2. Comparison of statistical indices obtained from predictive models in liver sausage

\begin{tabular}{cccccc}
\hline \hline \multirow{2}{*}{$\begin{array}{c}\text { Bacterial } \\
\text { type }\end{array}$} & Treatment $^{\mathrm{a}}$ & \multicolumn{4}{c}{ Statistical indices $^{\mathrm{b}}$} \\
\cline { 3 - 6 } & & $R^{2}$ & $\mathrm{~B}_{\mathrm{f}}$ & $\mathrm{A}_{\mathrm{f}}$ & RSME \\
\hline \multirow{3}{*}{$\begin{array}{c}\text { Total plate } \\
\text { counts }\end{array}$} & $\mathrm{C} 1$ & 1.007 & 0.9987 & 1.0012 & 0.03 \\
& $\mathrm{~T} 2$ & 0.908 & 1.0007 & 1.0045 & 0.03 \\
& $\mathrm{~T} 3$ & 0.978 & 1.0184 & 1.0066 & 0.34 \\
\hline \multirow{2}{*}{ Anaerobic } & $\mathrm{C}$ & 0.940 & 1.0055 & 1.0008 & 0.03 \\
bacterial & $\mathrm{T} 1$ & 0.991 & 1.0015 & 1.0005 & 0.02 \\
counts & $\mathrm{T} 2$ & 0.983 & 1.0012 & 1.0042 & 0.07 \\
& $\mathrm{~T} 3$ & 1.000 & 0.9997 & 1.0000 & 0.03 \\
\hline \multirow{2}{*}{$\begin{array}{c}\text { Lactic acid } \\
\text { bacterial }\end{array}$} & $\mathrm{C} 1$ & 0.977 & 1.0084 & 1.0017 & 0.01 \\
counts & $\mathrm{T} 1$ & 0.927 & 1.0250 & 1.0165 & 0.03 \\
& $\mathrm{~T} 2$ & 0.966 & 1.0088 & 1.0041 & 0.05 \\
\hline
\end{tabular}

${ }^{a}$ Treatments comprised dried kimchi powder. Control, meat batter without kimchi powder; T1, meat batter with $1 \%$ kimchi powder; T2, meat batter with $2 \%$ kimchi powder; $\mathrm{T} 3$, meat batter with $3 \%$ kimchi powder.

${ }^{\mathrm{b}} B_{f}$, bias factors; $A_{f}$, accuracy factors; RMSE, root mean square error; $R^{2}$, determination of coefficient

approximately $0.15 \%$. A $B_{f}$ lower than $1\left(B_{f}<1\right)$ indicates a "fail safe" model (Paluumbo et al., 1991), while a $B_{f}$ higher than $1\left(B_{f}>1\right)$ indicates a "fail dangerous" model
(Nolan et al., 1992). Ross et al. (2000) also noted that for models describing pathogen growth rate, $B_{f}$ in the range of 0.7-0.9 or 1.06-1.15 is considered acceptable, and $B_{f}$ $<0.7$ or $B_{f}>1.5$ is considered unacceptable. Thus, the results for TPC, anaerobic bacteria and LAB models indicated that good predictions can be made by Baranyi models.

A mathematical modeling process usually begins with first-order models, which are mathematical formulae describing microbial growth or survival curves, expressed by a total plate count, toxin production, and level of substrates or level of metabolites (Kajak and Kolozyn-Krajewska, 2006). It can also be used to estimate the effects of various combinations of variables in food environments (Whiting, 1995). The modeling of specific pathogens in meat and meat products under various temperature ranges or different marination methods has been reported many times in the context of growth inactivation (Heo et al., 2009; Ross, 1999). However, the effectiveness of adding kimchi powder on microbial content of meat products has not been studied much to date.

In this study, only the primary model was applied to liver sausage with added kimchi powder. However, for more detailed assurance of microbiological safety and to 
estimate a more stable shelf-life, further estimations of the effects of various combinations of variables, such as storage temperature, salt level, or additives, should be taken into account in secondary modeling. Furthermore, data should be also applied to other predictive modeling equations, such as the modified logistic model and the Gompertz model, to find models more reliable and suitable for food products.

\section{Acknowledgments}

This work was funded by the Ministry of Agriculture and Forestry (106115-02-1-SB010), and the Rural Development Administration (PJ007399) in Korea. This study was also supported by the Priority Research Centers Program through the National Research Foundation of Korea funded by the Ministry of Education, Science and Technology (2009-0093824).

\section{References}

1. Baranyi, J. and Roberts, T. A. (1994) A dynamic approach to predicting bacterial growth in food. Int. J. Food Microbiol. 23, 277-294.

2. Baranyi, J. and Roberts, T. A. (1995) Mathematics of predictive food microbiology. Int. J. Food Microbiol. 26, 199-218.

3. Baranyi, J., Roberts, T. A., and McClure, P. J. (1993) Some properties of a non-autonomous deterministic growth model describing the adjustment of the bacterial population to a new environment. Math. Med. Biol. 10, 293-299.

4. Borch, E., Kant-Muermans, M. L., and Blixt, Y. (1996) Bacterial spoilage of meat and cured meat products. Int. J. Food Microbiol. 33, 103-120.

5. Choe, J. H., Han, D. J., Choi, J. H., Choi, Y. S., Kim, H. Y., Lee, M. A., An, K. I., and Kim, C. J. (2009) Effect of Kimchi powder levels and pork skin on the quality characteristics of liver sausage. Korean J. Food Sci. Ani. Resour. 29, 203-212.

6. Choi, J. H. and Kim, M. J. (2006) A study of securing agrifood safety at local production level and importing stage. KREI, Seoul, Korea.

7. Duffy, L. L., Vanderlinde, P. B., and Grau, F. H. (1994) Growth of Listeria monocytogenes on vacuum-packed cooked meats: effects of $\mathrm{pH}, \mathrm{a}_{\mathrm{w}}$, nitrite, and ascorbate. Int. J. Food Microbiol. 23, 377-390.

8. Food and Drug Administration. Bacteriological analytical manual. Available from: http://www.fda.gov/Food/Science Research/LaboratoryMethods/BacteriologicalAnalyticalManual BAM/default.htm. Accessed Jun. 30, 2010.

9. Jiménz Colmenero, F. (2000) Relevant factors in strategies for fat reduction in meat products. Trends Food Sci. Technol. 11, 56-66.

10. Kajak, K. and Kolozyn-Krajewska, D. (2006) Construction of predictive models of growth of microorganisms in salted and cured meat products. Inno. Food Sci. Emerg. Technol. 7, 152-159.

11. Kim, H. W., Choi, Y. S., Choi, J. H., Han, D. J., Kim, H. Y., Hwang, K. E., Song, D. H., and Kim, C. J. (2011) Effects of rice bran fiber on changes in the quality characteristics of raw ground pork during chilled storage. Korean J. Food Sci. Ani. Resour. 31, 339-348.

12. Matamoros, S., André, S., Hue, U., Prévost, H., and Pilet, M. F. (2010) Identification of lactic acid bacteria involved in the spoilage of pasteurized "foie gras" products. Meat Sci. 85, 467-471.

13. McDonals, K. and Sun, D. W. (1999) Predictive food microbiology for the meat industry: A review. Int. J. Food Microbiol. 52, 1-27.

14. McMeekin, T. A., Olley, J. N., Ross, T., and Rathowsky, D. A. (1993) Predictive microbiology: Theory and application. Research Studies Press Ltd., Taunton, NJ.

15. Nolan, D. A., Champlin, D. C., and Troller, J. A. (1992) Minimal water activity levels for growth and survival of Listeria monocytogenes and Listeria innocua. Int. J. Food Microbiol. 16, 323-325.

16. Notermans, S. and in't Veld, P. (1994) Microbiological challenge testing for ensuring safety of food products. Int. J. Food Microbiol. 24, 33-39.

17. Paluumbo, S. A., Williams, A. C., Buchanan, R. L., and Philips, J. G. (1991) Model for the aerobic growth of Aeromonas hydrophila K144. J. Food Protect. 55, 429-435.

18. Pirt, S. J. (1975) Growth lag. In: Principles of microbe and cell cultivation. Wiley, NY.

19. Roberts, T. A. (1995) Microbial growth and survival: Developments in predictive modeling. Int. Biodeterior. Biodegrad. 36, 297-309.

20. Ross, T. (1999) Predictive food microbiology models in the meat industry. Meat and Livestock Australia, Sydney, Australia.

21. Ross, T., Dalgaard, P., and Tienungoon, S. (2000) Predictive modeling of the growth and survival of Listeria in fishery products. Int. J. Food Microbiol. 62, 231-245.

22. Samelis, J., Kakouri, A., and Rementzis, J. (2000a) The spoilage microflora of cured, cooked turkey breasts prepared commercially with or without smoking. Int. J. Food Microbiol. 56, 133-143.

23. Samelis, J., Kakouri, A., and Rementzis, J. (2000b) Selective effect of the product type and the packaging conditions on the species of lactic acid bacteria dominating the spoilage microbial association of cooked meats at $4^{\circ} \mathrm{C}$. Food Microbiol. 17, 329-340.

24. Skandamis, P. N. and Nychas, G. E. (2000) Development and evaluation of a model predicting the survival of Escherichia coli O157:H7 NCTT 12900 in homemade eggplant salad at various temperatures, $\mathrm{pHs}$, and oregano essential oil concentrations. Appl. Environ. Microbiol. 66, 1646-1653.

25. Vasilopoulos, C., Ravyts, F., De Maere, H., De Mey, E., Paelinck, H., De Vuyst, L. (2007) Evaluation of the spoilage lactic acid bacteria in modified-atmosphere-packaged artisan-type cooked ham using culture-dependent and culture- 
independent approaches. J. Appl. Microbiol. 104, 1341-1353.

26. Vermeiren, L., Devlieghere, E., and Debevere, J. (2004) Evaluation of meat born lactic acid bacteria as protective cultures for the biopreservation of cooked meat products. Int. J. Food Microbial. 96, 149-164.

27. Whiting, R. C. (1995) Microbial modeling in foods. Crit. Rev. Food Sci. Nutr. 35, 467-494.

28. Yang, A., Brewster, M. J., Lanari, M. C., and Tume, R. K. (2002) Effect of vitamin E supplementation on $\alpha$-tocopherol and $\beta$-carotene concentrations in tissues from pasture- and grain-fed cattle. Meat Sci. 60, 35-40.

29. Yoon, Y., Skandamis, P. N., Kendall, P. A., Smith, G. C., and Sofos, J. N. (2006) A predictive model for the effect of temperature and predrying treatments in reducing Listeria monocytogenes populations during drying of beef jerky. J. Food Prot. 69, 62-70.

30. Youssef, M. K. and Barbut, S. (2011) Fat reduction in comminuted meat products-effects of beef fat, regular and preemulsified canola oil. Meat Sci. 87, 356-360. 